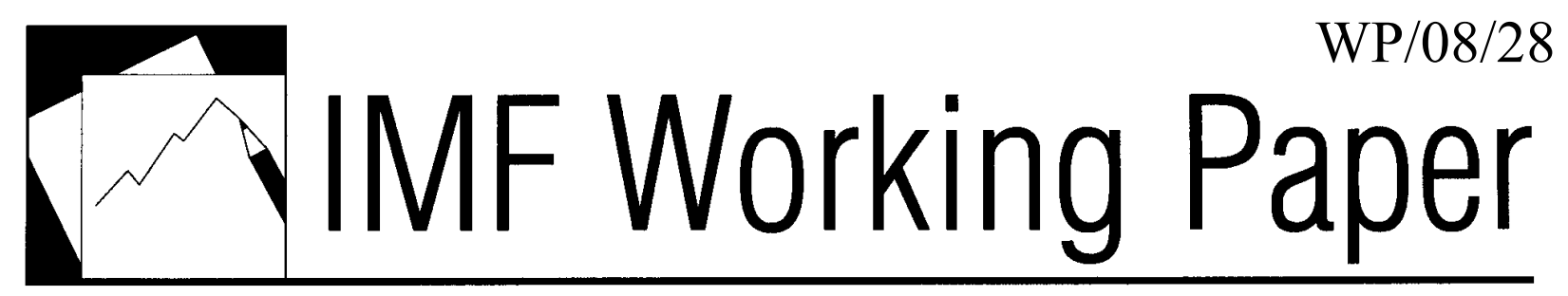

\title{
Where Did All the Borrowing Go? \\ A Forensic Analysis of the U.S. External Position
}

Philip R. Lane and Gian Maria Milesi-Ferretti 



\title{
IMF Working Paper
}

Research Department

\section{Where Did All the Borrowing Go? A Forensic Analysis of the U.S. External Position}

\section{Prepared by Philip R. Lane and Gian Maria Milesi-Ferretti ${ }^{1}$}

February 2008

\begin{abstract}
This Working Paper should not be reported as representing the views of the IMF. The views expressed in this Working Paper are those of the author(s) and do not necessarily represent those of the IMF or IMF policy. Working Papers describe research in progress by the author(s) and are published to elicit comments and to further debate.

The deterioration in the U.S. net external position in recent years has been much smaller than the extensive net borrowing associated with large current account deficits would have suggested. This paper examines the sources of discrepancies between net borrowing and accumulation of net liabilities for the U.S. economy over the past 25 years. In particular, it highlights and quantifies the role played by net capital gains on the U.S. external portfolio and 'residual adjustments' in explaining this discrepancy. It discusses whether these 'residual adjustments' are likely to be originating from measurement errors in external assets and liabilities, financial flows, or capital gains, and explores the implications of these conjectures for the U.S. financial account and external position.
\end{abstract}

JEL Classification Numbers:F31, F32

Keywords: Financial integration, capital flows, external assets and liabilities

Author's E-Mail Address:plane@tcd.ie; gmilesiferretti@imf.org

\footnotetext{
${ }^{1}$ Prepared for the TRIO conference (Tokyo, September 4-5 2007). We thank Vahagn Galstyan, Agustin Benetrix and Nathalie Ennis for excellent research assistance. Without implicating them, we are grateful to our discussant Shinji Takaji, seminar participants at Bruegel, IMF, LACEA 2007, Fundacion Ramon Areces, the Bureau of Economic Analysis, Ravi Balakrishnan, Tam Bayoumi, Tomas Dvorak, Ralph Kozlow, Guy Meredith and Jean Pisani-Ferry for their comments, and to Carol Bertaut and Frank Warnock for useful discussions. Lane also gratefully acknowledges the HEA-PRTLI grant to the IIIS.
} 
I. Introduction 3

II. Preliminaries 5

A. Dynamics of the Net Foreign Asset Position: A Benchmark Decomposition ...........5

B. Data and Empirical Methodology .....................................................................6

III. The International Investment Position: Key Features.....................................................

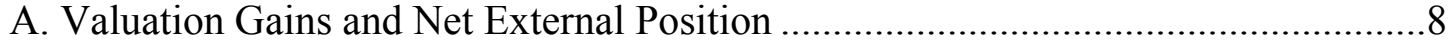

B. Components of the International Balance Sheet ................................................

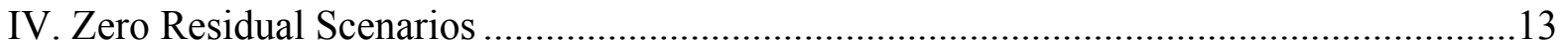

A. Method: New Estimates with Re-Allocated Data ...............................................13

B. Residual as capital gain .................................................................................. 14

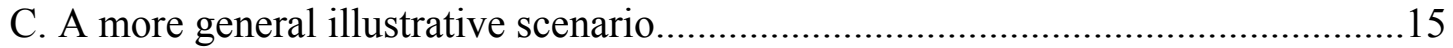

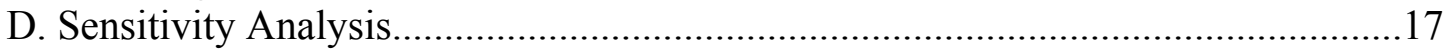

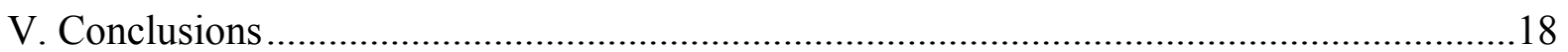

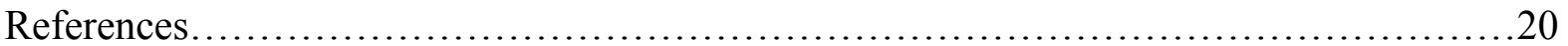

Figures

1. Net International Investment Position and Cumulative Financial Outflows................23

2. Net International Investment Position and Cumulative Valuation-Adjusted Financial

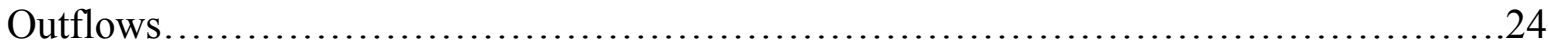

3. U.S. IIP: Stock-Flow Residual.................................................25

4. Decomposition of Stock-Flow Residual...........................................26

5. Implications of Alternative Scenarios for Net Foreign Asset Position.....................27

Tables

1. The Dynamics of the U.S. International Investment Position, 1976-2006................28

2. Price and Exchange Rate Valuation Effects, 1983-2006............................29

3. The Importance of Residual Adjustments, 1983-2006................................ 30

4. Portfolio Assets and Liabilities: Stock-Flow Reconciliation...........................31

5. Foreign Direct Investment: Stock-Flow Reconciliation................................32

6. Holdings of Banks and Non-Banks: Stock-Flow Reconciliation........................33

7. Rates of Capital Gain....................................................... 34

8. Net Impact of Residual "Re-Allocation" on External Position, Capital Flows,

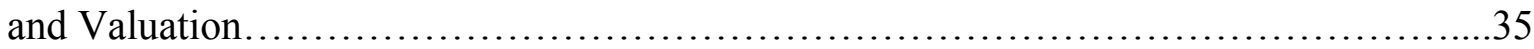




\section{INTRODUCTION}

The rapid growth in cross-border financial trade in recent years has posed new challenges to the understanding of external imbalances. First, it is increasingly well appreciated that capital gains and losses on existing holdings of foreign assets and liabilities can be as important as the current account balance in determining the dynamics of the net foreign asset position and that the importance of such valuation effects grows in line with the gross scale of international balance sheets (Lane and Milesi-Ferretti 2001, 2007a). Second, the increased number, size, and complexity of financial instruments and market participants engaged in cross-country transactions complicates significantly the statisticians' task of monitoring external accounts.

The recent experience of the United States provides a clear illustration of the scope for divergence between the current account balance and the change in net foreign assets. Despite average current account deficits of over 5 percent of GDP between 2002 and 2006, the U.S. net international investment position (IIP) - which measures the difference between U.S. external assets and liabilities - has remained broadly unchanged. ${ }^{2}$ Over a longer horizon, the cumulative U.S. current account deficit from 1983 to 2006 totaled over $\$ 5$ trillion, whereas the U.S. IIP worsened by less than $\$ 3$ trillion.

What explains this remarkable difference? Changes in net foreign assets should reflect either net financial flows or changes in the value of the U.S. external portfolio: hence, the difference highlighted above could be ascribed to "capital gains" due to shifts in asset prices and exchange rates. As documented by Gourinchas and Rey (2007b) and Lane and Milesi-Ferretti (2007b) these capital gains imply that the rate of return earned by U.S. residents on their external assets is significantly higher than the return earned by foreign residents on U.S. assets. In turn, this has implications for the sustainability of the U.S. current account deficits (see, for example, Kitchen, 2007 and Meredith, 2007). However, Curcuru, Dvorak, and Warnock (2007) have recently shown that, over the past decade, average market rates of return on financial instruments comparable to U.S. portfolio assets and liabilities respectively do not display large differences in returns. Others have argued that measured return differentials are evidence of a substantial underestimation of the level of U.S. external assets (Hausmann and Sturzenegger, 2007).

In this paper we attempt to provide an explanation for these contrasting findings. In particular, we highlight the significant role played by "residual adjustments" —not linked to measured financial flows or estimated capital gains - in explaining the dynamics of the U.S. external position. ${ }^{3}$ In any given period, these adjustments - which typically result from refinements or extended coverage of the statistical methods used to capture international transactions and

\footnotetext{
${ }^{2}$ Net external liabilities measured with FDI at current cost are unchanged as a ratio of GDP between 2001 and 2006, while net liabilities measured at market value have actually declined in absolute terms.

${ }^{3}$ The Bureau of Economic Analysis (BEA), which reports data on U.S. international transactions and positions, decomposes the change in the IIP into the contribution of net financial flows, valuation gains associated with movements in market prices and exchange rates, and a residual "other adjustments" term.
} 
holdings — suggest some past measurement problem in (a) financial flows; (b) capital gains; and/or (c) initial positions. Because they give rise to discrepancies between financial flows and the change in the corresponding holdings of assets and liabilities, they are often considered together with valuation changes as part of capital gains and losses on a country's external portfolio. To the extent that these residual adjustments do not display any systematic pattern, they would only introduce noise in the measurement of implicit rates of return on external assets and liabilities. However, adjustments follow a systematic pattern in U.S. data-hence, attributing them entirely to capital gains significantly affects the measurement of rate of return differentials.

Accordingly, the goal of this paper is to conduct a "forensic" examination of changes in the U.S. external position, to investigate the extent to which these residual adjustments could be attributed to measurement error in financial flows, capital gains, and initial positions. In addition to its central role in the current global configuration of external imbalances, the United States is a natural candidate for a case study due to the high quality of its balance of payments statistics. The BEA provides a more detailed breakdown of the IIP than is available for most countries, and for a significant time period. Moreover, its publications provide a transparent description of the measurement challenges it has faced and the choices it has made in revising the statistics over time.

This line of research is highly relevant in assessing the likely future path for the U.S. external position. In particular, some authors (see, for example, Kitchen, 2007) consider that these systematically positive "net discrepancies" will continue in the future and hence limit the need for U.S. current account adjustment. An accurate decomposition of the relative role of net capital gains and financial flows is also centrally important in guiding the new generation of open-economy macroeconomic models that feature endogenously-determined international portfolios. ${ }^{4}$

Our work relates to several recent contributions. Gourinchas and Rey $(2007 \mathrm{a}, \mathrm{b})$ and Lane and Milesi-Ferretti (2007b) examine the dynamics of the U.S. external position but do not differentiate between net capital gains and the residual adjustment term. The paper by Curcuru et al. (2007) is closer to our work. It investigates whether there have been systematic differences in rates of return between portfolio assets held by U.S. residents overseas and foreign holdings of U.S. portfolio instruments, and conclude that for the period 1994-2005 this is not the case. It also argues that the positive return differential on portfolio instruments calculated from balance of payments data is due to the fact that revisions to estimates of U.S. holdings overseas - which have on average been positive - are not fully reflected in upward revisions to U.S. portfolio outflows, thus raising estimates of U.S. returns overseas (because the difference between the change in holdings and measured portfolio outflows is attributed to capital gains). While we also draw the implications of data revisions for the measurement of returns on portfolio instruments, we seek to understand the evolution of the entire U.S. external position from a longer-term perspective (1983-2006). A related line of research has studied the reasons why the

\footnotetext{
${ }^{4}$ See, inter alia, Cavallo and Tille (2006), Devereux and Sutherland (2006), Tille and van Wincoop (2007) and Kollmann et al (2007).
} 
net investment income balance for the United States has remained positive, despite a large negative net foreign asset position. ${ }^{5}$ However, our primary focus in this paper is on the split between the current account and net capital gains, rather than on the differences between the yields on U.S. external assets and liabilities.

The structure of the rest of the paper is as follows. Section II reviews the data and conceptual issues that guide the subsequent analysis. Section III discusses the evolution of the U.S. IIP in the aggregate as well as for the individual components of the U.S. international balance sheet. We turn to some alternative scenarios in Section IV, while Section V offers some conclusions.

\section{Preliminaries}

The well-known difference between the cumulative external borrowing of the United States and its net external position is shown in Figure 1 for the periods 1976-1982, 1983-1992, 1993-2001, and 2002-2006. The Figure shows that cumulative net capital outflows tend to understate the U.S. external position by the end of all sub-periods. The extent of such understatement - that we call "gap"-is relatively modest for the first three periods but is very large for 2002-2006 (19 percent of GDP when FDI is measured at current cost, and 25 percent when it is measured at market value). Table 1 provides some additional insights by showing the changes in total foreign assets, foreign liabilities and the net foreign asset position and the cumulative financial outflows, financial inflows and financial account. A striking feature from Table 1 is that the gap between financial flows and the change in positions is primarily driven by the asset side of the international balance sheet, consistent with the general pattern whereby capital outflows are more difficult to track than capital inflows (Lane and Milesi-Ferretti 2007a). In order to explain these stylized facts, we first provide an accounting decomposition of changes in the net external position and then briefly describe the underlying data.

\section{A. Dynamics of the Net Foreign Asset Position: A Benchmark Decomposition}

The evolution of a country's stocks of external assets and liabilities is given by

$$
\begin{gathered}
A_{t}=A_{t-1}+V A L_{t}^{A}+F_{t}^{A}=A_{t-1}+k g r_{t}^{A}\left(A_{t-1}+0.5 F_{t}^{A}\right)+F_{t}^{A} \\
L_{t}=L_{t-1}+V A L_{t}^{L}+F_{t}^{L}=L_{t-1}+k g r_{t}^{L}\left(L_{t-1}+0.5 F_{t}^{L}\right)+F_{t}^{L}
\end{gathered}
$$

where $V A L_{t}$ is the net capital gain, $k g r_{t}$ the 'rate of capital gain' and $F_{t}$ is the financial flow. Note that holdings for year $t$ are measured at the end of the year, while the flows for year $t$ accrue throughout the year. For simplicity, we assume that capital gains accruing from exchange

\footnotetext{
${ }^{5}$ Cline (2005) and Hausmann and Sturzenegger (2007) capitalize the investment income streams into alternative estimates of the net foreign asset position. See also Buiter (2006), Gros (2006a, 2006b), Higgins et al (2006), Heath (2007), and Kitchen (2007) on the investment income debate.
} 
rate and asset price changes are earned on 50 percent of the current-period flow, in addition to the outstanding position inherited from the previous period.

However, all variables — stocks, flows, and valuation effects - are potentially measured with some degree of error. The observed dynamic equations are

$$
\begin{aligned}
& A_{t}^{M}=A_{t-1}^{M}+k g r_{t}^{M, A}\left(A_{t-1}^{M}+0.5 F_{t}^{M, A}\right)+F_{t}^{M, A}+O_{t}^{M, A} \\
& L_{t}^{M}=L_{t-1}^{M}+k g r_{t}^{M, L}\left(L_{t-1}^{M}+0.5 F_{t}^{M, L}\right)+F_{t}^{M, L}+O_{t}^{M, L}
\end{aligned}
$$

where the superscript $M$ denotes the measured value in the data and $O_{t}$ is aggregate measurement error. Clearly, measurement error can affect all terms in equations (3) and (4): financial flows, holdings, and capital gains. In what follows, we examine different hypotheses concerning the source of the measurement error term. On the one hand, since financial globalization has dramatically increased financial flows and gross foreign assets and liabilities relative to GDP, a constant 'rate of measurement error' translates into a larger percentage of GDP. On the other hand, improvements in data collection and statistical methodologies may serve to reduce the 'rate of measurement error' over time.

\section{B. Data and Empirical Methodology}

At the end of June each year, the BEA releases its official estimate of the U.S. IIP for the end of the previous year. It also publishes a stock-flow reconciliation table showing the change in each component of the position as the sum of financial flows, valuation gains associated with price and exchange rate movements, and 'other' changes. This 'other' category includes 'changes in coverage, capital gains and losses of direct investment affiliates, and other adjustments to the value of assets and liabilities." A July article in the Survey of Current Business describes the main features of the new IIP estimates as well as the reasons for the changes relative to the previous year.

These initial IIP estimates may be subsequently revised for a variety of reasons: for example, the results of the survey of portfolio asset holdings for year $t$ becomes available at the end of year $t+1$, but are not yet available in June of that year when the initial IIP estimate for the previous year is released. Each July, the BEA publishes in the Survey of Current Business an annual article explaining the new revisions to the historical data. The BEA has also recently published an updated reconciliation table encompassing the subsequent revisions to stock, flow, and valuation data. ${ }^{6}$ These data, currently available for the period 1989-2006, are provided in less detail than in the annual stock-flow reconciliation table - in particular, no breakdown is provided among the individual categories of external assets and liabilities.

We use the BEA data to estimate the decomposition of 'revised' valuation adjustments for individual asset categories. First, we take the original release of the stock-flow reconciliation

\footnotetext{
${ }^{6}$ See Clarida et al (2007).
} 
table which shows the contribution of each component to the change in the position in a given period

$$
P O S_{i t}^{\text {orig }}=P O S_{i t-1}^{\text {orig }}+F_{i t}^{\text {orig }}+V A L_{i t}^{M V, \text { orig }}+V A L_{i t}^{X R, \text { orig }}+R E S I D_{i t}^{\text {orig }}
$$

where the superscript orig denotes the original data, $P O S_{i t-1}$ is the position at the end of the previous year, $F_{i t}$ is the current-period financial flow, $V A L^{M V}$ and $V A L^{X R}$ denote the valuation gains associated with changes in asset prices and exchange rates respectively, and RESID is the residual adjustment term.

As in Curcuru et al. (2007), we calculate the 'rate of capital gain' by

$$
k g r_{i t}=\frac{V A L_{i t}^{M V, \text { orig }}+V A L_{i t}^{X R, o r i g}}{P O S_{i t-1}^{o r i g}+0.5 F_{i t}^{\text {orig }}}
$$

The BEA calculates capital gains by applying yield-stripped rates of return from market indices to the estimated position data. ${ }^{7}$ Next, we can calculate a revised valuation term (where, for simplicity, we aggregate between market price and exchange rate terms)

$$
V A L_{i t}^{P, r e v}=k g r_{i t}\left(P O S_{i t-1}^{r e v}+0.5 F_{i t}^{r e v}\right)
$$

Where the superscript rev denotes revised data and $V A L^{P}=V A L^{M V}+V A L^{X R}$. In turn, this implies that the revised residual term is

$$
R E S I D_{i t}^{r e v}=\left(P O S_{i t}^{r e v}-P O S_{i t-1}^{r e v}\right)-F_{i t}^{r e v}-V A L_{i t}^{P, r e v}
$$

These series provide stock-flow decompositions for each investment category that are consistent with the revised data. In section IV below, we make further rounds of adjustments that seek to allocate the residual term across the various potential sources of mis-measurement, in order to attain a final 'zero residual' set of estimates.

\footnotetext{
${ }^{7}$ The BEA does periodically revise its return indices, but we do not have access to the revised valuation data for individual asset categories. In some cases, we update capital gain calculations using stock-flow reconciliation tables from the Treasury surveys of U.S. holdings of foreign portfolio securities (which are more up-to-date than the original IIP releases) or information on asset price changes from market indices.
} 


\section{The International InVestment Position: Key features}

We can now turn to the role played by financial flows, price and valuation effects, and other factors in explaining the evolution of the U.S. IIP - first in the aggregate, and then turning to the different components of the U.S. external portfolio.

\section{A. Valuation Gains and Net External Position}

The impact of asset price and exchange rate fluctuations on the value of external assets and liabilities depends critically on the asset and currency composition of the external position. With regard to currency composition, the overwhelming majority of U.S. foreign-currency holdings are in equity-type instruments (FDI and portfolio equity) — which are also sensitive to asset price fluctuations. With regard to U.S. external liabilities (almost entirely denominated in U.S. dollars), FDI and portfolio equity liabilities are those most sensitive to asset price fluctuations, because most debt liabilities are of a relatively short maturity. As a result, valuation effects on U.S. external assets are primarily driven by the behavior of international stock prices measured in U.S. dollars, while valuation effects on U.S. external liabilities are linked to the behavior of U.S. stock prices as well as U.S. interest rates, given the significant size of U.S. bond liabilities.

Tables 2 shows the quantitative contribution of valuation changes in explaining the GAP term highlighted in Table 1. We report two measures of valuation changes - one derived from the revised BEA stock-flow reconciliation table (available for the period 1989-2006) and the other based on the decomposition method for the individual asset and liability series described in section 2 (implemented back to 1983 and labeled LMF). ${ }^{8}$ The net contribution of valuation effects was actually negative during 1983-1992 and 1993-2001 but turned strongly positive during 2002-2006.

These results can be explained as follows. During the period 1983-92, stock prices (expressed in a common currency) increased at similar rates in the United States and the rest of the world. However, for most of the period U.S. equity liabilities were significantly larger than U.S. equity assets, and hence the valuation term was negative. For the period 1993-2001, U.S. stock prices rose much more rapidly than those in the rest of the world, a difference amplified by the appreciation of the U.S. dollar. This explains the sharply negative net valuation effects during the period. During 2002-2006 these conditions were instead reversed: U.S. stock prices trailed stock prices in the rest of the world, also on account of a significant dollar depreciation. With much larger holdings of external assets and liabilities as a share of GDP than in earlier periods, valuation effects were correspondingly magnified.

\footnotetext{
${ }^{8}$ The decomposition of changes in holdings of FDI at market value for 1983-1992 is hampered by the fact that the BEA has not released the details on the stock-flow reconciliation for that category prior to 1989. For the purpose of our calculations, we have assumed that the entire difference between the change in the stock of FDI assets and liabilities at market value and the respective flows for 1983-92 can be ascribed to price and exchange rate valuation effects (in line with the fact that 'other adjustments' play a modest role in explaining changes in holdings of FDI at market value in subsequent periods). The BEA and LMF measures are quite similar for 1993-2001 and 2002-2006.
} 
To what extent do valuation effects help explain the pattern of stock-flow discrepancies presented at the beginning of Section 2? As shown in Figure 2, valuation effects go a significant way towards explaining the stock-flow discrepancies for the period 2002-2006, but they actually widen the discrepancy between stocks and flows during 1983-92 and 1993-2001. Indeed, Figure 3 shows that the residual adjustment term has been consistently positive throughout each period. It also shows that our approximation to the calculation of the 'residual' term matches the BEA residuals quite closely. Although the net residual has been roughly stable as a percentage of GDP across the periods, the gross residuals for foreign assets and liabilities have increased sharply in recent years, as documented in Table 3. A noteworthy feature is that the residual terms tends to be positive for foreign assets but have been negative in some periods for foreign liabilities.

Taken together, Tables 2 and 3 highlight that valuation effects can be either negative or positive depending on the relative trends in U.S. and foreign asset prices and movements in the dollar exchange rate but that valuation gains are central in understanding the insulation of the U.S. net foreign asset position during 2002-2006 from the consequences of a cumulatively large current account deficit. The residual adjustment term is also a quantitatively significant factor, and it is useful to investigate whether it is likely to reflect hidden capital gains, unrecorded flows, or mis-measured initial positions. To address this issue, we turn to a more detailed examination of the timing and sources of 'residual' adjustments, making use of the detailed documentation on IIP estimates and subsequent data revisions published by the BEA in the Survey of Current Business.

\section{B. Components of the international balance sheet}

To construct a time series of updated 'residual' adjustments for individual IIP series, we rely on the decomposition method discussed in Section II. In evaluating the key measurement issues in each category, we base our interpretation on the detailed annual articles from the BEA that describe the components of the IIP, the sources of revisions to previously-released data, and the adjustments made to the financial flow data in the TIC system in order to align them with balance-of-payments concepts. ${ }^{9}$ In addition, we draw on the additional information provided by the U.S. Treasury in the releases of the results of their regular surveys of U.S. portfolio assets and liabilities.

\section{Portfolio Assets and Liabilities: Bonds}

The net portfolio debt position of the United States has steadily grown more negative over the whole sample period. Table 4 shows that valuation gains have played a modest role in this respect, in part because of the relatively small foreign-currency component in both portfolio debt assets and liabilities. Rather, residual adjustments are the main source of the gap between cumulative flows and the change in positions. A striking feature is that the residual adjustment is consistently positive for portfolio debt assets (assets increase more than indicated by

\footnotetext{
${ }^{9}$ The "International Investment Position of the US at Yearend" and "Annual Revision of the US International Accounts" articles all appear in the July issue of the BEA's Survey of Current Business. Methodological articlessuch as Landefeld and Lawson (1991) - provide additional insights.
} 
cumulative foreign bond purchases, adjusted for estimated valuation changes) but negative for portfolio debt liabilities.

The residual for assets for 1983-92 and 1993-2001 can be linked to a lack of survey data on portfolio bond holdings: the 1994 U.S. Treasury survey of portfolio asset holdings overseas was the first since $1943 .{ }^{10}$ For the 2002-06 period, the 2003 portfolio survey highlighted a massive discrepancy relative to the 2001 survey and 2002-2003 flows - $\$ 375$ billion, or 75 percent of portfolio debt asset holdings. This led to a strengthening of data collection on foreign bond purchases, and to a revision in bond outflows for 2002-03 of \$120 billion. However, this revision still left a very significant residual gap.

In regard to portfolio debt liabilities, the main source of the significant negative residuals for the period 1993-2001 were the results of the March 2000 portfolio liability survey, which found foreign U.S. bonds holdings to be $\$ 400 \mathrm{bn}$ lower than previously estimated (on the basis of the 1994 survey and subsequent flows). A number of shortcomings in the measurement of flows were identified, such as an incomplete reporting of redemptions of maturing securities and lack of coverage of principal repayments on asset-backed securities. As a result, the BEA revised downwards bond inflows for the period 1995-1999, to an extent that accounted for about half of the residual for Treasury securities and a larger share of the residual for agency and corporate bonds. Still, the remaining residual remains significant (Table 4). ${ }^{11}$

For the period 2002-2006 surveys are available on an annual basis. The main source of the negative residual are the findings of the June 2003 and June 2005 portfolio liability surveys, both of which found foreign holdings of U.S. bonds to be well below the level estimated on the basis of previous surveys' data and subsequent flows. Again the survey articles point to a likely overestimation of bond inflows, but since flow data were not revised downwards significantly the residual remains important. ${ }^{12}$

\section{Portfolio Assets and Liabilities: Equity Holdings}

Portfolio equity assets and liabilities increased by similar amounts during 1983-2001, with only a minor shift in the net position (bottom part of Table 4). In contrast, the net portfolio equity position improved by 12 percentage points of GDP during 2002-2006, primarily driven by a large positive differential between the valuation gains earned on foreign equity assets relative to those on equity liabilities (in contrast with the pattern in the previous periods). Expressed as a

\footnotetext{
${ }^{10}$ This still predates the wider adoption of portfolio surveys by other countries: the IMF's Coordinated Portfolio Investment Survey (CPIS) was started on a trial basis only in 1997; it now includes a large number of countries and has taken place annually since 2001 .

${ }^{11}$ See the July 2002 SCB article on the annual revision to U.S. International Accounts, and Griever et al. (2003).

${ }^{12}$ The 2003 and 2005 Portfolio Liability surveys mention again the role of repayments on asset-backed securities, not properly captured by the capital flow data (particularly for the 2003 survey), as well as the under-reporting of maturing securities, which leads to an overstatement of foreigners' net purchases of U.S. debt securities (2005 survey).
} 
ratio to GDP, residual terms on the asset side have been positive and significant in all periods, exceeding those on the liability side.

As is the case for portfolio debt assets, the reasons for the discrepancy in the first two subperiods is primarily associated with the findings of the 1994 portfolio survey, which identified much larger U.S. holdings of foreign equities than had been previously estimated by the BEA (a difference of about $\$ 300 \mathrm{bn}-4$ percent of GDP and 75 percent of previously estimated holdings). For this reason, the stocks of portfolio equity asset holdings were revised upwards for the period 1984-1993. ${ }^{13}$ However, the portfolio equity flows for these years were not revised, leading to a large residual adjustment term. We can look at two extreme hypotheses with regard to this residual term. If it is attributed to additional valuation effects, it would imply a rate of return on portfolio equity holdings exceeding the ones calculated from the MSCI world minus U.S. index —or from the BEA adjustment method — by about 10 percentage points per year for that decade. If instead the stock-flow discrepancy for 1984-94 reflects underestimated flows, this would imply a decline in U.S. net borrowing (the U.S. financial account balance) by about 0.3 percentage points of GDP per year for the period 1984-94.

Subsequently, the 1997 survey also identified equity holdings by U.S. residents overseas which were \$200bn higher than estimated. This was used to correct positions from 1994-1997 and, for the first time, equity outflows, but by about $\$ 60$ billion in total, leaving a significant positive residual. ${ }^{14}$ For the 2002-2006 period, most of the discrepancy originates in the results of the portfolio survey for end-2005, which found U.S. equity holdings exceeding those estimated on the basis of the survey for end-2004 and 2005 equity outflows by over $\$ 200$ billion. The difference is substantial in absolute terms, but has to be related to the increased size of external assets and liabilities - it constitutes 7.5 percent of the initially estimated stock of U.S. portfolio equity assets.

With regard to portfolio equity liabilities, the residual is positive and largest for the period 2002-2006. It is primarily due to the findings of the 2002 and 2003 surveys, which identified higher holdings than those estimated on the basis of past surveys and subsequent flow data and valuation changes. No significant revisions to flows were adopted as a result of these survey findings, partly in light of the fact that valuation changes are quantitatively much for important for equity holdings than for bonds.

Overall, for the portfolio category, it is likely that measurement problems with financial flows over time have contributed significantly to the residual term. ${ }^{15}$ Griever et al (2001) and Bertaut

\footnotetext{
${ }^{13} 1984$ was selected as the cut-off year for revisions, since it marked the beginning of the period of rapid growth in cross-border portfolio transactions.

${ }^{14}$ The 2001 survey was used to correct positions for 1998-2001 and flows over 1998-2002. In 2004, it was also used to correct position and flow data over 1994-1997 (to take account of improvements in capturing foreign stock price movements). Since then, the annual survey is used to correct the initial estimates of positions and flows.

${ }^{15}$ There may be some degree of error in the 'rate of capital gain' term, since the BEA does not calculate capital gains by measuring the returns on a security-by-security basis.
} 
et al (2006) provide a detailed description of the difficulties in measuring cross-border securities transactions. While several of these problems have been addressed in recent years (for example, corrections for securities swaps and redemptions of asset-backed securities), some underestimation in net portfolio outflows remains a plausible explanation for the gaps between the portfolio survey results and that predicted by valuation-adjusted measured flows, particularly for bonds.

\section{Foreign Direct Investment}

The data for foreign direct investment (at current cost and market value) are reported in Table 5. Similar to the portfolio equity category, the net FDI position has improved substantially over the period 2002-2006 - especially at market value, which reflects the evolution of stock pricesand by considerably more than the cumulative increase in net outflows. Again, price and exchange rate valuation effects are the key factor explaining these developments, particularly for FDI at market value - the net valuation term has shifted from negative to positive between 1993-2001 and 2002-2006. ${ }^{16}$

Since the FDI positions are rooted in quinquennial surveys, the BEA has a high degree of confidence in the quality and coverage of the FDI data. ${ }^{17}$ Accordingly, the primary source of "other" adjustments are valuation shifts that do not fall into the regular "price" and "exchange rate" components. For instance, this may include the once-off gain from a disposal at a price greater than the recorded book value of an asset. For the current-cost measure, the other adjustment is employed to correct for the fact that flows are measured at market value and so do not capture the change in the current-cost value of assets and liabilities. The "residuals" can therefore mostly be related to valuation adjustments.

\section{Non-Portfolio Positions of Banks and Non-Banks}

We consider the non-portfolio positions of banks and non-banks in Table 6. Although cumulative flows explain the vast bulk of the shift in positions in this category, the residual

\footnotetext{
${ }^{16}$ For FDI measured at current cost, the net residual term has been positive and higher than for FDI at market value. This difference reflects a feature of current-cost accounting: since flows are measured at market values, an adjustment factor is needed to reconcile the flow with the change in the position at current cost, particularly in the case of large acquisitions. During the late 1990s, there were several large acquisitions of U.S. firms by foreign investors, but the value of U.S. FDI liabilities at current cost rose by less than the market value of such acquisitions, implying a negative "other adjustment" term for FDI liabilities for the period 1993-2001.

${ }^{17}$ Until 1991, the FDI positions were measured on a historical-cost basis. At that date, the BEA switched to two alternative measures (current-cost and market value) and retrospectively implemented these methodologies back to 1982 (see Landefeld and Lawson 1991). In 2000, the current-cost methodology was further modified and this led to revised current-cost estimates over 1982-1999. Beginning in 1994, intercompany debt transactions between parent companies and affiliates that are not depository institutions and that are primarily engaged in financial intermediation are reclassified from the direct investment accounts to capital transactions with unaffiliated foreigners (part of the portfolio investment accounts). Accordingly, there is a break in the FDI data (assets and liabilities) in 1994.
} 
factor is also significant and has partially offset the negative impact on the net position of large net capital inflows in this category. The TIC system collects the data on the non-portfolio holdings of banks and non-banks in the form of end-of-period positions, with flows inferred from the change in positions, net of adjustment terms.

Since this category covers loans, bank deposits and short-term paper, and trade credits, capital gains in this category are limited. The BEA documentation clearly show that stock-flow discrepancies for banking and nonbanking data on non-portfolio positions are primarily due to changes in coverage. The data for the positions reported by banks and non-banks are collected in regular surveys. In turn, financial flows are inferred from the change in the position in a given period, net of some adjustment terms. Since the scope of these surveys has progressively expanded over time and the methodology improved, the most plausible explanation for the residual term is the change in coverage: in effect, the estimated flow can be viewed as the change in position that can be attributed to the existing set of reporters, while the residual term relates to the positions of new reporters.

\section{IV. 'ZERO RESIDUAL' SCENARIOS}

Since the preceding analysis has shown that residual adjustments are quantitatively important for the dynamics of the U.S. external position, we are interested in exploring alternative estimates that re-allocate the residuals to some combination of flows, valuation gains and initial positions in order to produce an alternative set of 'zero residual' accounts. In order to impose some discipline, our re-allocation choices are guided by the explanations for the residuals that we discussed in the previous section.

\section{A. Method: New Estimates with Re-Allocated Data}

If the residual term is fully allocated to unrecorded financial flows, this implies a revision in both net flows and valuation effects, since part of valuation gains and losses accrues on withinyear financial flows. Specifically

$$
\begin{gathered}
F L O W_{i t}^{N}=F L O W_{i t}^{r e v}+R E S I D_{i t}^{r e v} \\
V A L_{i t}^{N}=\left(P O S_{i t}^{r e v}-P O S_{i t-1}^{r e v}\right)-F L O W_{i t}^{N} \\
k g r_{i t}^{N}=\frac{V A L_{i t}^{N}}{P O S_{i t}^{r e v}+0.5 F L O W_{i t}^{N}}
\end{gathered}
$$

If the residual term is instead allocated to mis-measured capital gains in a given category, then the new estimates for the valuation term and the 'rate of capital gain' are given by

$$
V A L_{i t}^{N}=\left(P O S_{i t}^{r e v}-P O S_{i t-1}^{r e v}\right)-F L O W_{i t}^{r e v}
$$




$$
k g r_{i t}^{N}=\frac{V A L_{i t}^{N}}{P O S_{i t}^{r e v}+0.5 F L O W_{i t}^{r e v}}
$$

Finally, if the residual is allocated to a mis-measured initial position (for example, because data coverage has subsequently been expanded), we re-estimate positions as follows. We assume that the ratio of financial flows $F L O W$ and valuation effects $V A L$ during year $t$ to the estimated position as of year $t-1$ is correctly measured and equal to $g$. We take the position in the final year of the sample $P O S_{i T}^{\text {rev }}$ (the one relying on the most extensive data coverage) to be correctly estimated, and calculate new adjusted positions $P O S_{i T}^{N}$ backward as follows:

$$
P O S_{i T-1}^{N}=\frac{P O S_{i T}^{r e v}}{1+g_{i T}} ; \quad P O S_{i t-1}^{N}=\frac{P O S_{i t}^{r e v}}{1+g_{i t}}
$$

where $T$ is the final year in the sample period. In turn, this implies new estimates for flows and capital gains

$$
\begin{gathered}
F L O W_{i t}^{N}=F L O W_{i t}^{R E V} \frac{P O S_{i t-1}^{N}}{P O S_{i t-1}^{R E V}} \\
V A L_{i t}^{N}=V A L_{i t}^{R E V} \frac{P O S_{i t-1}^{N}}{P O S_{i t-1}^{R E V}}
\end{gathered}
$$

\section{B. Residual as capital gain}

We start by asking what are the implications of considering that flows and holdings data are appropriately measured, and the residual term reflects mis-measurement of net capital gains. As discussed earlier, this is the method applied in Lane and Milesi-Ferretti (2007b) and Gourinchas and Rey (2007b). Table 7 reports estimated 'rates of capital gain,' including both 'full residual' estimates (where all the residual is re-allocated to the capital gain term) and our estimates that are primarily based on the original release of the BEA data (which in turn reflects market returns). Reflecting the large positive residual factors in this category, the 'full residual' approach produces much higher estimates of the rate of capital gain on portfolio equity and debt assets than are generated by market returns, which in some periods (the 1980s for portfolio equity, and in the first and last period for bonds) are clearly not realistic. Estimates are more similar on the liabilities side.

While re-allocating the residual to the capital gains term would - for portfolio instrumentsdrive a significant wedge between the estimated rate of capital gain and the rate that might be inferred from various indices of market-based rates of return, the situation is different for FDI. Indeed, a number of adjustments comprised in the "other" category are more akin to valuation 
gains and losses (for example, realized capital gains or losses of direct investment affiliates). ${ }^{18}$ For FDI measured at current cost, attributing the residual to valuation gains tends to raise the difference in capital gains and returns between external assets and liabilities. Both methods generate instead similar estimates for the rates of capital gain in the FDI at market value category (data not reported).

With respect to total external assets and liabilities, in the most recent period price and exchange rate valuation effects account for a 4 percent return differential between assets and liabilities when FDI is measured at current cost, and 51/2 percent when FDI is measured at market value. Attributing the entire residual to capital gains raises the return differential between capital gains on assets and liabilities by about 2 percentage points. ${ }^{19}$

\section{A more general illustrative scenario}

In this illustrative scenario, we draw on the themes highlighted in Section III by allocating the residual terms to particular sources in each investment category. In particular, we allocate the residuals in portfolio positions to mis-measured flows; mis-measured capital gains for FDI positions; and mis-measured initial positions for the non-portfolio positions of banks and nonbanks. ${ }^{20}$ In each case, we also discuss alternative re-allocation options and draw out the implications for the estimated rates of capital gain.

For foreign portfolio assets and liabilities, the re-allocation of the residual to financial flows is prompted by the resources expended on annual surveys of portfolio positions in recent years, which suggests that positions are likely to be well measured. In addition, BEA estimates of the 'rate of capital gain' are likely to be a good proxy for the true rate, since they are constructed using market return indices, corrected for currency movements. For these reasons, the primary source of measurement error in this category is likely to be in the financial flows component. Indeed, Thomas et al (2006), Bertaut et al (2006) and Curcuru et al (2007) also ascribe the gap to mis-measured flows and create alternative flow series to interpolate positions between survey dates for U.S. portfolios.

As was discussed in the previous section, the primary source of other adjustments in the FDI positions relates to the realization of capital gains that are not captured by the standard 'price'

\footnotetext{
${ }^{18}$ On the other hand, the calculation of the price and exchange rate valuation terms for FDI is more problematic than for portfolio equity, because most FDI holdings are unlisted. In particular, the BEA estimates capital gains on FDI assets (at market value) by applying the return in the stock market of the host country. This may not be fully accurate for export-platform FDI or if the sectoral composition of FDI deviates from the mix in the local stock market index.

${ }^{19}$ As well documented, the United States also enjoys a favorable yield differential on its external assets relative to its external liabilities. As a result, the total return differential between external assets and liabilities is larger than the capital gain differential.

${ }^{20}$ Allocating the residual term to flows or capital gains does not alter the estimated series for positions. In contrast, allocating the residual term to mis-measured positions leads to revisions to the series for positions, flows and capital gains.
} 
term in the BEA decomposition. Since it is notoriously difficult to establish a correct market value for FDI positions, it is not too surprising that it is difficult to easily fit capital gains into a standard 'price' term that is based on broad market indices. Especially since the FDI position and flow data are anchored by a long history of regular and comprehensive surveys, we consider the capital gains term to be the most plausible source of the residual component.

Finally, we view the residual term for the non-portfolio positions of banks and non-banks as primarily reflecting measurement error in initial positions. This is motivated by the increase in coverage in the holdings surveys in these categories: in effect, the reported flow can be viewed as the change in position that can be attributed to the existing set of reporters, while the residual term relates to the positions of new reporters.

Table 8 sketches the implications for estimated flows, valuation terms, and estimated positions under this alternative scenario. It shows the difference between the revised cumulative financial flows, valuation effects, and changes in the external position, and the corresponding official figures (reported in Tables 4-6). These differences are significant. Table 8 highlights that, under the admittedly crude assumption that portfolio holdings and the rate of capital gain are correctly estimated, but portfolio financial flows are not, "revised" net portfolio outflows would be higher than the measured outflows in all three periods (by about 1 percent of GDP a year for 20022006). While net portfolio equity flows account for the bulk of the difference for the 1983-1992 period, net bond outflows are the major factor for 1993-2006, reflecting the results of the surveys discussed more extensively in Section III.

Table 8 also shows a larger role for valuation changes, on account of the contribution of the valuation gains on the larger net portfolio outflows as well as those on FDI. As for data on the non-portfolio holdings of banks and non-banks, the widening scope of the surveys suggest that past holdings - and consequently flows, since these are calculated from the holdings data - may have been underestimated. In our calculations, this implies a somewhat faster deterioration in the U.S. external position than according to official data (that is, some underestimation of past U.S. net foreign assets).

Figure 4 shows the relative contributions of revisions to flows, valuation and positions in our reallocation of the residual term. The figure shows that the relative importance of each term fluctuates over time but that the dominant factor in recent years (especially if FDI is measured at market value) in our approach is the flow component. In contrast, the adjustment in positions is most important in the earlier years in the sample period, reflecting the substantial expansion in coverage over time.

Putting together the elements of this alternative scenario would raise estimated net financial outflows from the United States by around 0.6 percent of GDP per year since 1983 - a significant amount. Absent revisions in the estimated current account position, this would imply — ceteris paribus - that the measured U.S. current account deficit has exceeded net financial outflows from the United States by around 0.7 percent of GDP a year on average since 
the early 1980s. ${ }^{21}$ While changes to the financial account and external holdings would automatically have some impact on the current account (through net investment income earnings as well as through exports and imports of financial services), these would be one order of magnitude smaller than the financial account revisions. ${ }^{22}$ Since the trade balance is measured largely independently from the financial account, it is difficult to see how significant corrections to the trade balance can be made. Hence, any solution to the "residual puzzle" creates another puzzle, by complicating the task of aligning the financial flows with the US current account deficit.

\section{Sensitivity Analysis}

As a sensitivity analysis, we take a more flexible approach by attributing a fraction $\alpha$ of the portfolio residual to mis-measured flows (rather than the entire amount as in the previous section), with the remainder of the residual allocated to a mis-measured initial stock. ${ }^{23}$ Corrected flows $F L O W^{\alpha}$ are the given by

$$
F L O W_{t}^{\alpha}=F L O W_{t}+\alpha \frac{\operatorname{RESID}_{t}}{1+k g r_{t} / 2}
$$

Revised stocks can be constructed backwards as follows:

$$
P O S_{t}=P O S_{t-1}^{\alpha}\left(1+k g r_{t}\right)+F L O W_{t}^{\alpha}\left(1+k g r_{t} / 2\right)
$$

For $\mathrm{t}=2006$, actual and revised final stocks are the same. This implies

$$
\operatorname{POS}_{t-1}^{\alpha}=\frac{P O S_{t}}{1+k g r_{t}}-F L O W_{t}^{\alpha} \frac{1+k g r_{t} / 2}{1+k g r_{t}}
$$

and for preceding years

$$
P O S_{t-s-1}^{\alpha}=\frac{P O S_{t-s}^{\alpha}}{1+k g r_{t-s}}-F L O W_{t-s}^{\alpha} \frac{1+k g r_{t-s} / 2}{1+k g r_{t-s}}
$$

Setting $\alpha=1$ is equivalent to attributing all the residual to flows, as in our baseline experiment. Figure 5 shows the impact on the net foreign asset position over 1983-2006 for different values of $\alpha(0,1 / 4,1 / 2,3 / 4,1)$. Although the choice has little effect for the most recent years, there is

\footnotetext{
${ }^{21}$ On the basis of published U.S. data, the average statistical discrepancy between net financial outflows and the current account balance is about 0.1 percent per year. Revising net financial outflows upward by 0.6 percent leads to a widening of the average discrepancy.

${ }^{22}$ For example, a 5 percent average yield means that adding 10 percentage points to the historical net foreign asset position would improve the current account balance by 0.5 percentage points.

${ }^{23}$ We thank Tomas Dvorak for this suggestion.
} 
considerable dispersion for earlier periods. For instance, if $\alpha=1 / 2$ the 1996 net foreign asset position would be 5 percentage points stronger and the 1983 position 11 percentage points stronger. The extreme case $(\alpha=0)$ would imply a 1996 position 10 percentage points stronger and the 1983 position 22 percentage points stronger.

Higher estimates for the net foreign asset position in earlier years would also imply a more positive investment income balance (which is typically estimated by applying market yields to outstanding assets and liabilities) and hence a more positive current account balance. For example, in the case of $\alpha=1 / 2$, the prevailing yields on portfolio debt and portfolio equity holdings during the 1980s and 1990s imply that the net investment income balance would improve by an annual average of 0.8 percent of GDP during 1983-1989 and 0.3 percent of GDP during 1990-1999. ${ }^{24}$ Such an improvement in the current account would "explain" on average the larger then recorded capital outflows (the positive "flow residual") without raising the statistical discrepancy between the current account and the financial account.

In summary, we would doubt the relevance of "high $\alpha$ " scenarios - they would imply implausibly large asset holdings in the portfolio category in early years (and simply push the mismeasurement of net financial outflows backwards in time). Nevertheless, it is clearly possible that U.S. external assets were somewhat underestimated, particularly in the earlier period of our sample during which portfolio surveys were not conducted. In turn, this underestimation could explain part of the discrepancy between the current account and net financial outflows that the under-recording of the latter would imply.

\section{Conclusions}

We have provided evidence on the factors underlying the evolution of the U.S. external positions, highlighting the role of financial flows and valuation gains, as well as residual adjustments. We have documented that these residual adjustments have on average contributed to improving the U.S. external position, and we have investigated whether the residuals are more likely to capture unrecorded financial flows, mis-measured stock positions, or mismeasured capital gains.

One option is to attribute the entire residual to capital gains. This tends to raise the measured return differential between U.S. external assets and liabilities by about 2 percentage points over the past 15-20 years. However, on the basis of a careful scrutiny of the sources of revisions, we have argued that the residual is unlikely to reflect mis-measured capital gains to that extent. In particular, a good proportion of the residual adjustment could well reflect unrecorded financial flows, especially in the portfolio category, while a mis-measured initial position is another contributory factor, especially in the non-portfolio holdings of banks and non-banks. We have presented alternative scenarios that, consistent with these observations, allocates the residual across all three sources. These scenarios suggest that the extent of net financial flows to the

\footnotetext{
${ }^{24}$ In practice, the investment income component of the current account is measured by applying market yields to estimated asset and liability positions. In this way, an alternative estimate of the net foreign asset position directly implies an alternative value for net investment income.
} 
United States over the past 25 years may have been overstated by up to 0.6 percent of GDP per year. In turn, this would imply that that the U.S. average current account deficit would exceed net financial outflows by up to 0.7 percent of GDP on average during this period-hence addressing the stock-flow reconciliation puzzle leads to the emergence of a new puzzle.

Whether systematic "residuals" are likely to remain a feature of the data despite continuous improvements in statistical methodologies and the quality of surveys is an open issue. In particular, the speed of financial innovation, the rapid growth in the pool of cross-border investors, and the scale and complexity of financial transactions means that the reconciliation of the financial flow data and the international position data will remain a challenging task. For this reason, researchers should devise methods to allocate residuals in a sensible manner, in order to make assessments about the relative roles of financial flows and valuation gains in driving the dynamics of the net external position.

We have also shown that price and exchange rate valuation gains arising from asset price developments and the U.S. dollar depreciation are still key to understanding the stability of the U.S. external position over the past 5 years despite record external borrowing, regardless of the treatment of the residual term. This stands in contrast to the 1983-1992 and 1992-2001 periods when price and exchange rate valuation effects favored foreign investors in the United States. However, the extent of these recent gains, which are related to the substantial dollar weakening since 2002 and the differential returns in equity markets, cannot simply be extrapolated to the future. Although some further dollar depreciation may be a feature of the unwinding of global imbalances, a continuous negative trend in the value of the dollar would be hard to envisage without implications for U.S. inflation and interest rates. And over longer horizons there is no evidence of U.S. equity returns significantly underperform returns in the rest of the world.

However, there remain two factors that can still cushion the future deterioration in the U.S. external position. First, the evidence still points to a positive yield and return differential between U.S. external assets and liabilities, which reduces the scale of the trade balance adjustment necessary to eventually stabilize the U.S. external position. An important component of this differential is the higher yield on U.S. direct investment assets relative to the yield earned by foreign direct investors in the U.S. - a much-debated issue that we have not discussed in this paper. In addition, recent years have seen a shift in the composition of the U.S. international balance sheet, with equity and FDI heavily favored on the asset side, while the debt share of liabilities has grown rapidly with the decline in equity flows to the U.S. and the increasing prominence of bond purchases, including by foreign official investors. Since the potential for capital gains is greater on equity components than on debt, the asymmetric structure of the U.S. international balance sheet could well imply net capital gains on average in the future. Of course, the downside to this strategy is that reliance on debt financing increases vulnerability to a shift in the risk appetite of investors. 


\section{References}

Bertaut, Carol C., William L. Griever, and Ralph W. Tryon, 2006, "Understanding U.S. CrossBorder Securities Data," Federal Reserve Bulletin, A59-A75.

Buiter, Willem, 2006, "Dark Matter or Cold Fusion?" Goldman Sachs Global Economics Paper no. 136, January.

Cavallo, Michele and Cédric Tille, 2006, "Could Capital Gains Smooth a Current Account Rebalancing?”, Federal Reserve Bank of New York Staff Report 237

Clarida, Richard, Manuela Goretti, and Mark Taylor, 2007, "Are There Thresholds of Current Account Adjustment in the G7?," in Clarida, R. (ed.) G7 Current Account Imbalances: Sustainability and Adjustment, The University of Chicago Press, 169-200.

Griever, William, Gary Lee, and Francis Warnock, 2001, "The U.S. System for Measuring Cross-Border Investment in Securities: A Primer with a Discussion of Recent Developments," Federal Reserve Bulletin, October.

Cline, Bill, 2005, The United States as a Debtor Nation, Institute for International Economics and Center for Global Development.

Curcuru, Stephanie E., Tomas Dvorak and Frank Warnock, 2007, "The Stability of External Imbalances: The Role of Return Differentials,” NBER Working Paper No. 13074.

Devereux, Michael B. and Alan Sutherland, 2006, "Solving for Country Portfolios in Open Economy Macro Models,” CEPR Discussion Paper 5966, November.

Gourinchas, Pierre-Olivier and Hélène Rey, 2007a, "From World Banker to World Venture Capitalist: US External Adjustment and the Exorbitant Privilege", Clarida, R. (ed.) G7 Current Account Imbalances: Sustainability and Adjustment, The University of Chicago Press, 11-55.

Gourinchas, Pierre-Olivier and Hélène Rey, 2007b, "International Financial Adjustment," Journal of Political Economy 115 no. 4, August, 665-703.

Griever, William, G Lee and Frank Warnock, 2001, "The US System for Measuring CrossBorder Investment in Securities: A Primer with Discussion of Recent Developments," Federal Reserve Bulletin 87(10), 633-650.

Gros, Daniel, 2006a, "Foreign Direct Investment in the U.S. (I): Disappearing into a Black Hole?” CEPS Working Document no. 242, April.

Gros, Daniel, 2006b, "Foreign Investment in the US (II):Being Taken to the Cleaners?" CEPS Working Document no. 243, April. 
Hausmann, Ricardo and Federico Sturzenegger, 2006 "Global Imbalances or Bad Accounting? The Missing Dark Matter in the Wealth of Nations and Its Implications for Global Imbalances," Economic Policy 22 (July), 469-518.

Heath, Alexandra, 2007, "What Explains the U.S. Net Income Balance?” BIS Working Paper 223, January.

Higgins, Matthews, Thomas Klitgaard, and Cedric Tille, 2007, "Borrowing without Debt? Understanding the U.S. International Investment Position," Business Economics 42 (1), 17-27.

Ihrig, Jane and Jaime Marquez, 2006, "Modeling Direct Investment Valuation Adjustments and Estimating Quarterly Positions," Federal Reserve Board International Financial Discussion Paper No. 857.

Kitchen, John, 2007, "Sharecroppers or Shrewd Capitalists? Projections of the US Current Account, International Income Flows, and Net International Debt," Review of International Economics 15 no. 5 (November), 1036-1061.

Landefeld, J. Steven and Ann M. Lawson, 1991, "Valuation of the U.S. Net International Investment Position," Survey of Current Business, May, 40-49.

Lane, Philip R., and Gian Maria Milesi-Ferretti, 2001, "The External Wealth of Nations: Measures of Foreign Assets and Liabilities for Industrial and Developing Countries," Journal of International Economics, Vol. 55, pp. 263-94.

,2003, “International Financial Integration," IMF Staff Papers, Vol. 50 Special Issue, pp. 82-113 (Washington, D.C.: International Monetary Fund).

_2005, "Financial Globalization and Exchange Rates," IMF Working Paper 05/03, January.

-2007a, "The External Wealth of Nations Mark II," Journal of International Economics 73 no. 2 (November), 223-50.

,2007b, "A Global Perspective on External Positions," in Clarida, R. (ed.) G7 Current Account Imbalances: Sustainability and Adjustment, The University of Chicago Press, 67-98.

McGuire, Patrick, 2004, “A shift in London's eurodollar market”, BIS Quarterly Review, September, 67-78.

McGuire, Patrick and Nikola Tarashev, 2006, "Tracking International Bank Flows," BIS QuarterlyReview, December, 27-40. 
Meredith, Guy, 2007, "Debt Dynamics and Global Imbalances: Some Conventional Views Reconsidered," IMF Working Paper 07/4, January.

Obstfeld, Maurice, 2004, “External Adjustment," Review of World Economics 140 (4), 541-568.

Survey of Current Business, various issues. "The U.S. International Investment Position”, July.

Survey of Current Business, various issues. "Revisions to International Accounts."

Tille, Cédric, 2003, "The Impact of Exchange Rate Movements on U.S. Foreign Debt," Current Issues in Economics and Finance 9(1), Federal Reserve Bank of New York.

— 2005, "Financial Integration and the Wealth Effect of Exchange Rate Fluctuations," Federal Reserve Bank of New York Staff Report no. 226.

_ and Eric van Wincoop, 2007, "International Capital Flows," NBER Working Paper No. 12856 .

Warnock, Frank E. and Chad Cleaver, 2003, "Financial Centers and the Geography of Capital Flows," International Finance 6 no. 1, 27-59. 
Figure 1. Net International Investment Position and Cumulative Financial Outflows (in percent of GDP)

\section{A. FDI at current cost}

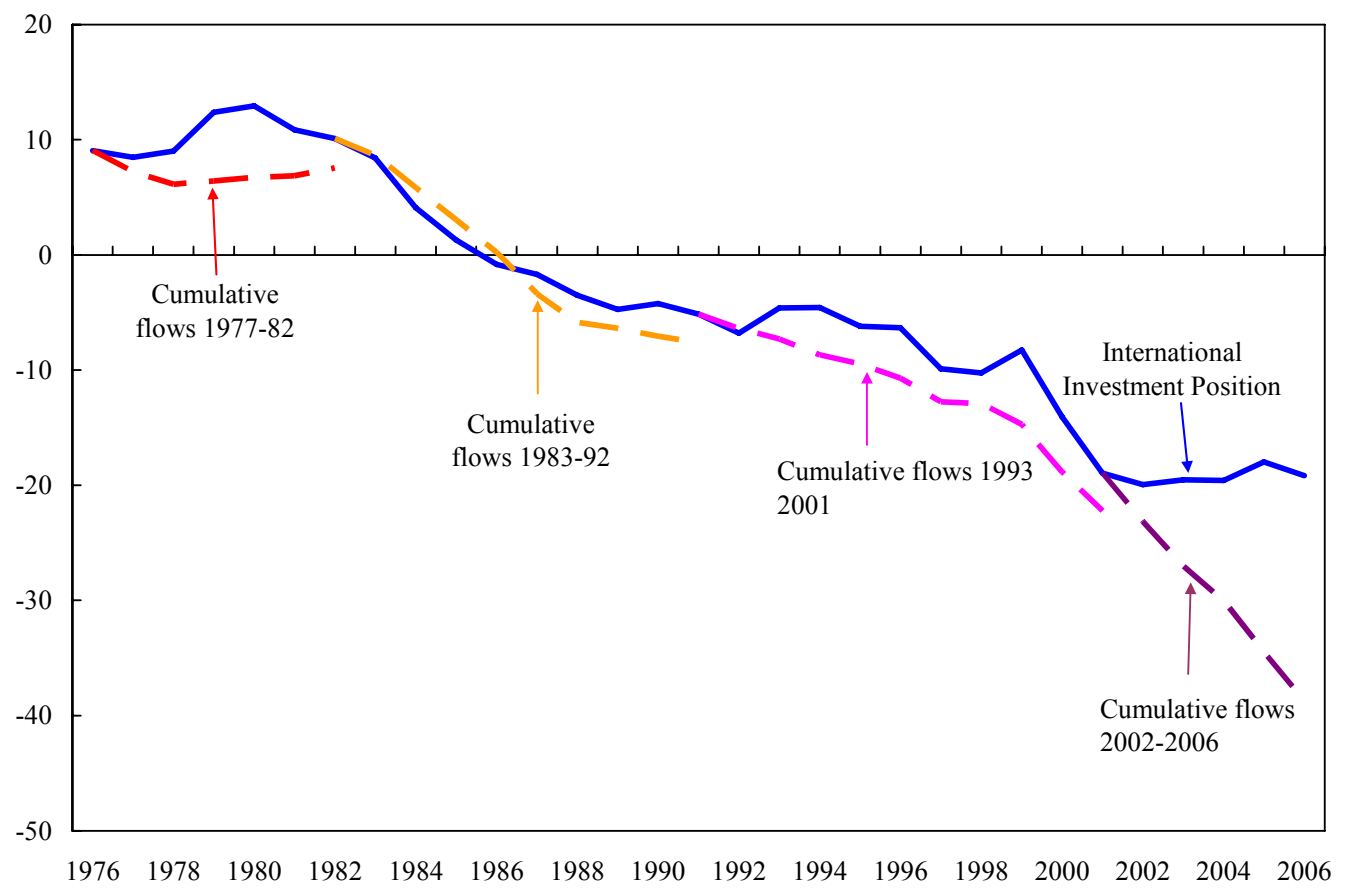

B. FDI at market value

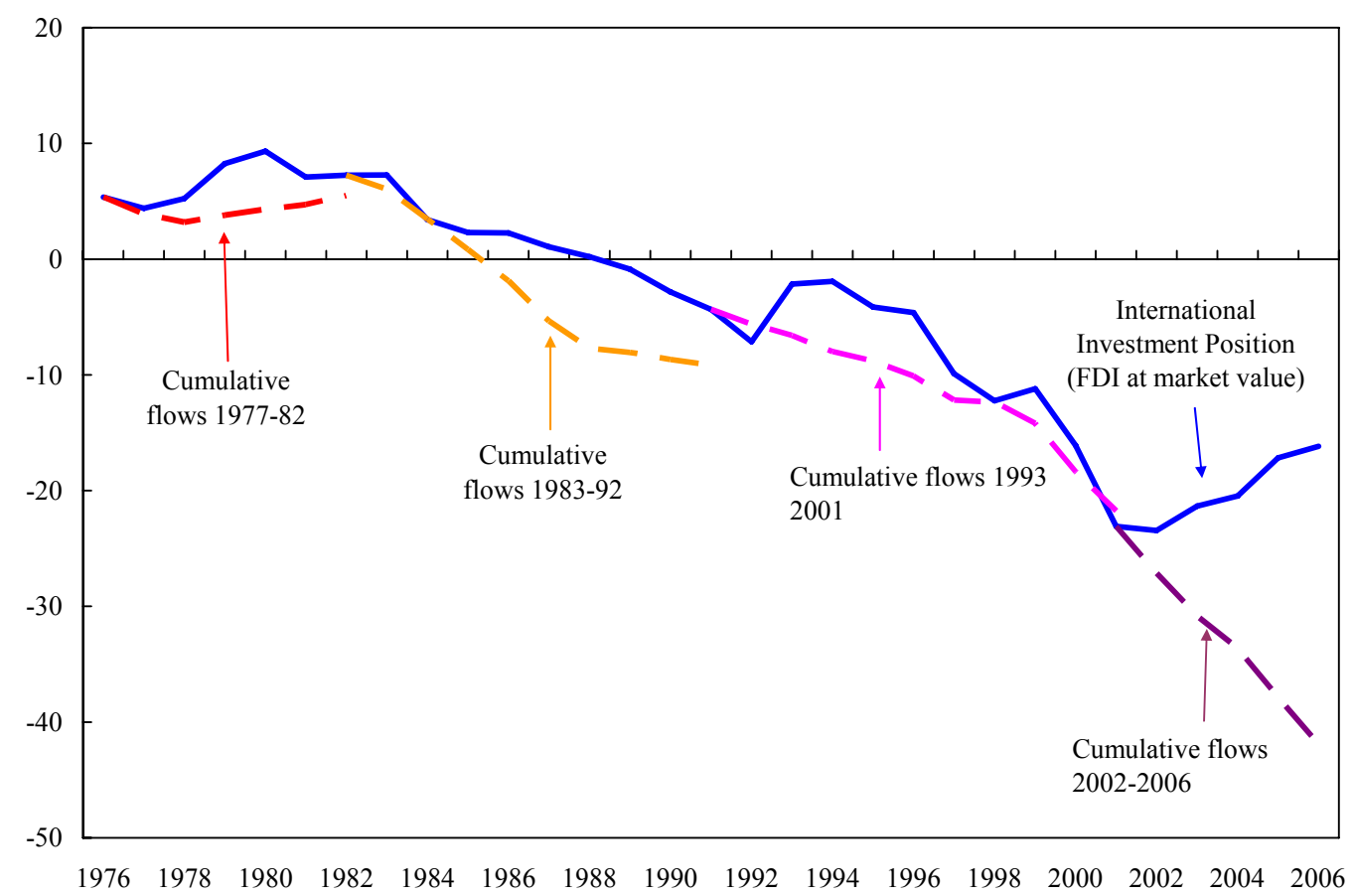


Figure 2. Net International Investment Position and Cumulative Valuation-Adjusted Financial Outflows (in percent of GDP)

\section{A. FDI at current cost}

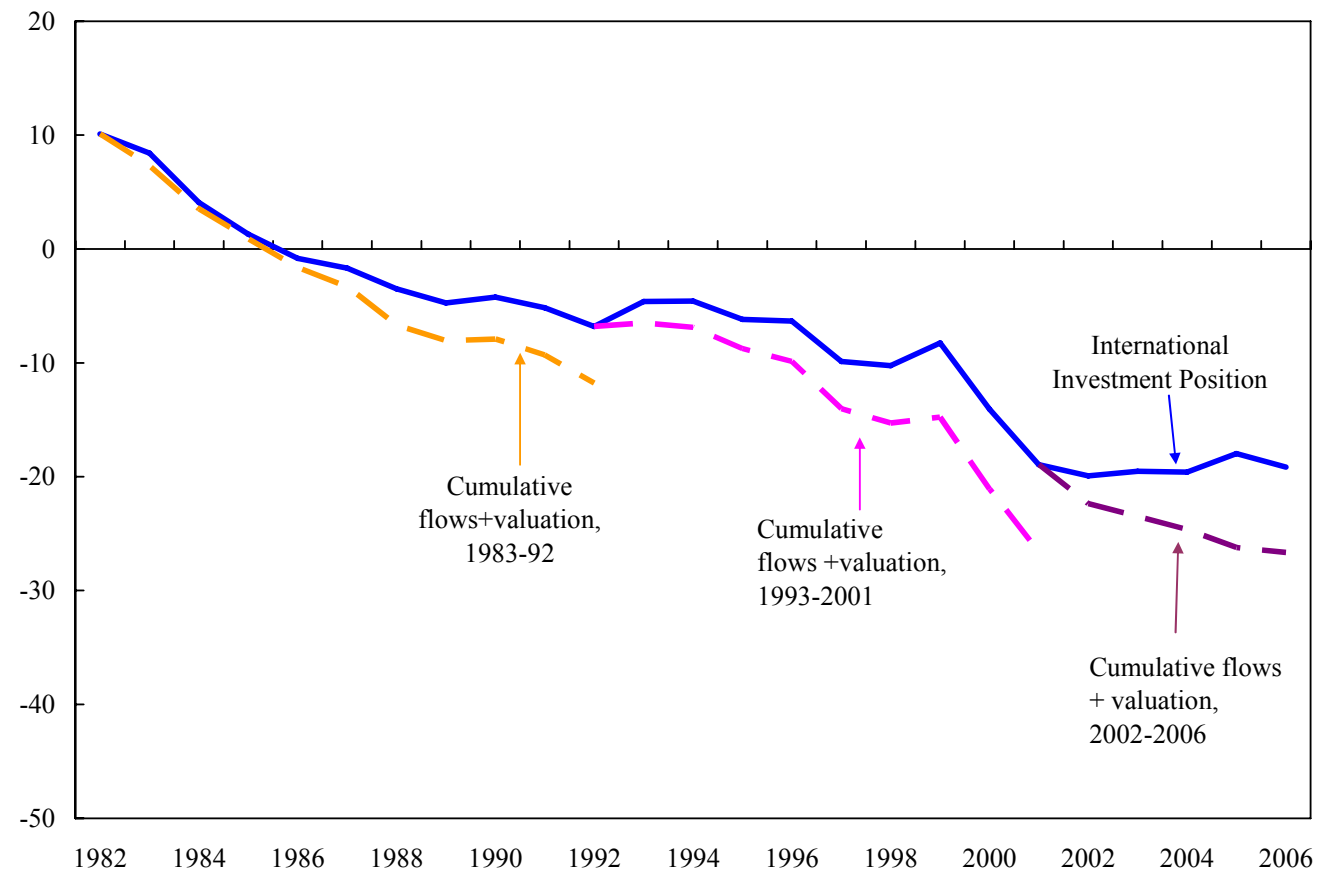

B. FDI at market value

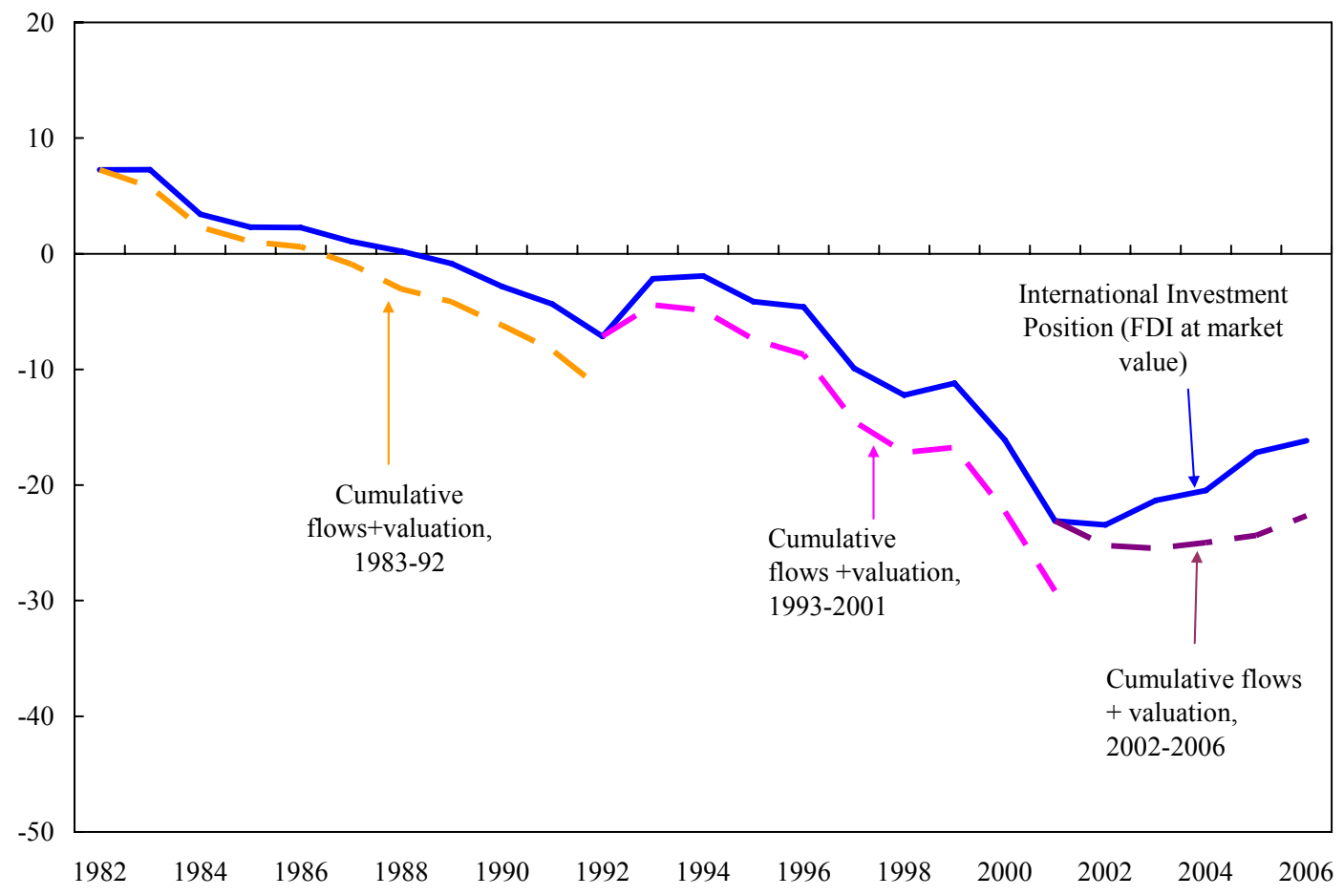


Figure 3. U.S. IIP: Stock-Flow Residual (in percent of GDP)
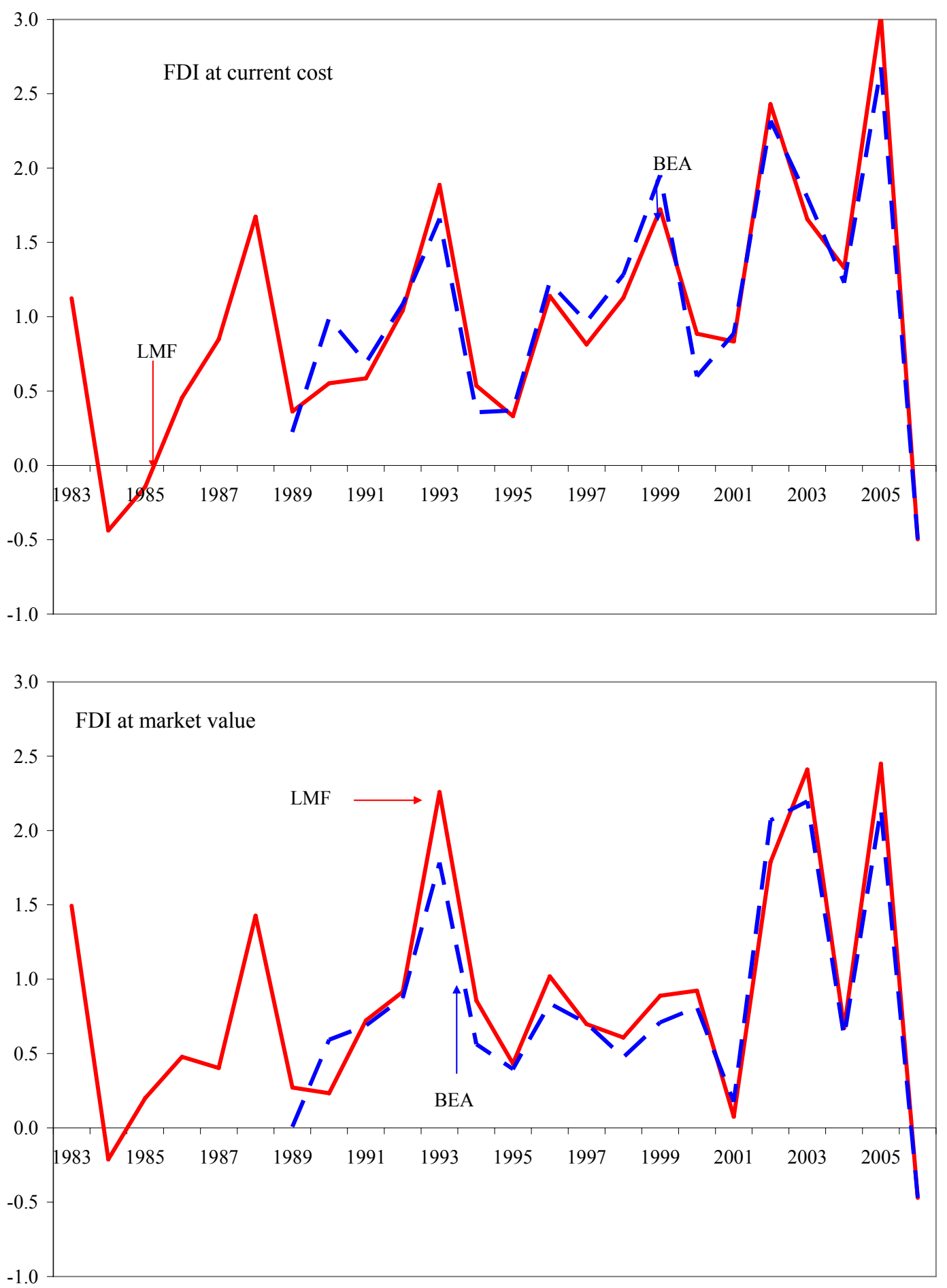

Note: The "BEA" line plots the ratio to GDP of "other changes" (from the table "Components of changes in the net international investment position." The LMF line plots our estimates of "other changes" derived from the individual asset and liability series and BEA data. 
Figure 4. Decomposition of Stock-Flow Residual (in percent of GDP)
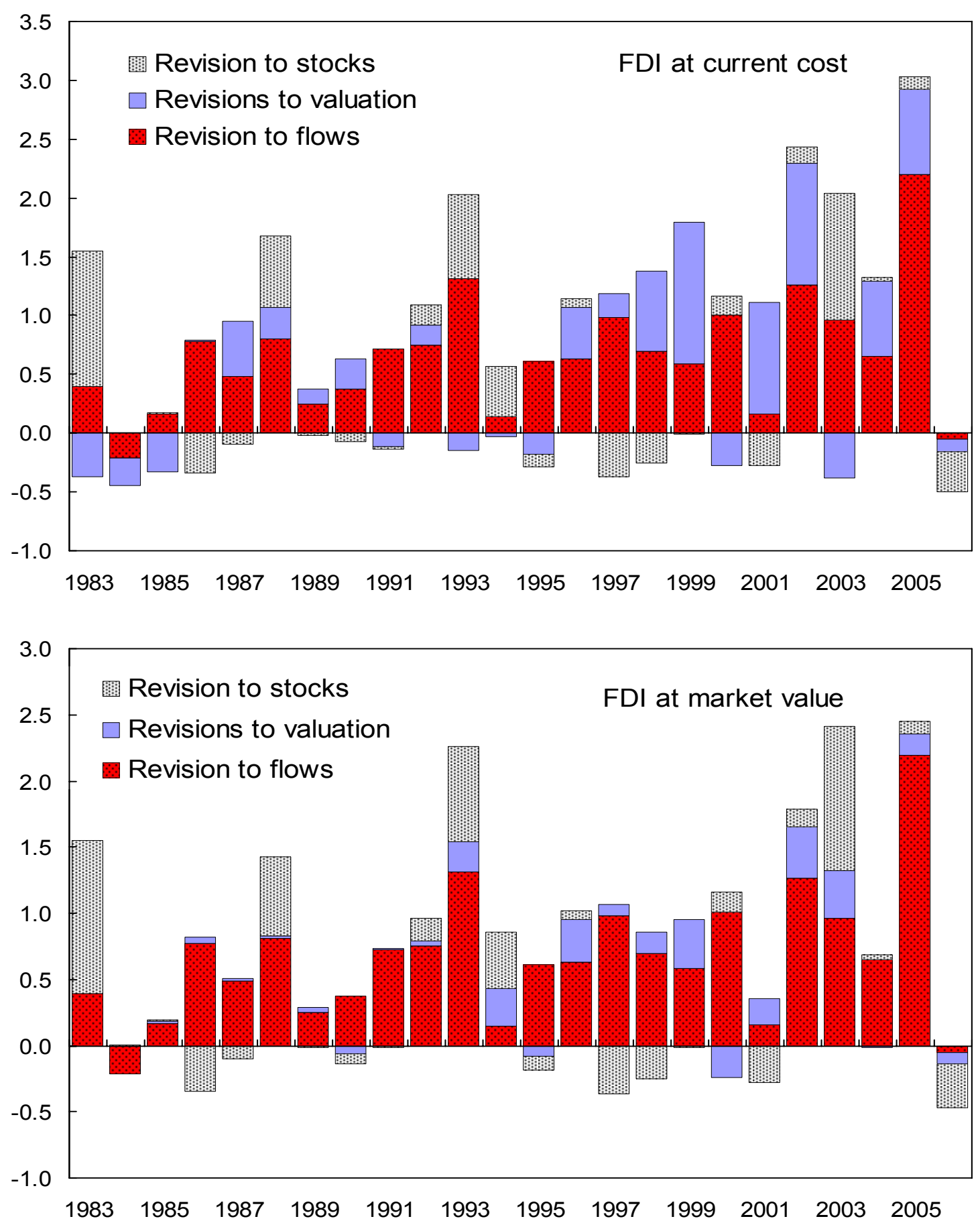
Figure 5. Implications of Alternative Scenarios for Net Foreign Asset Position

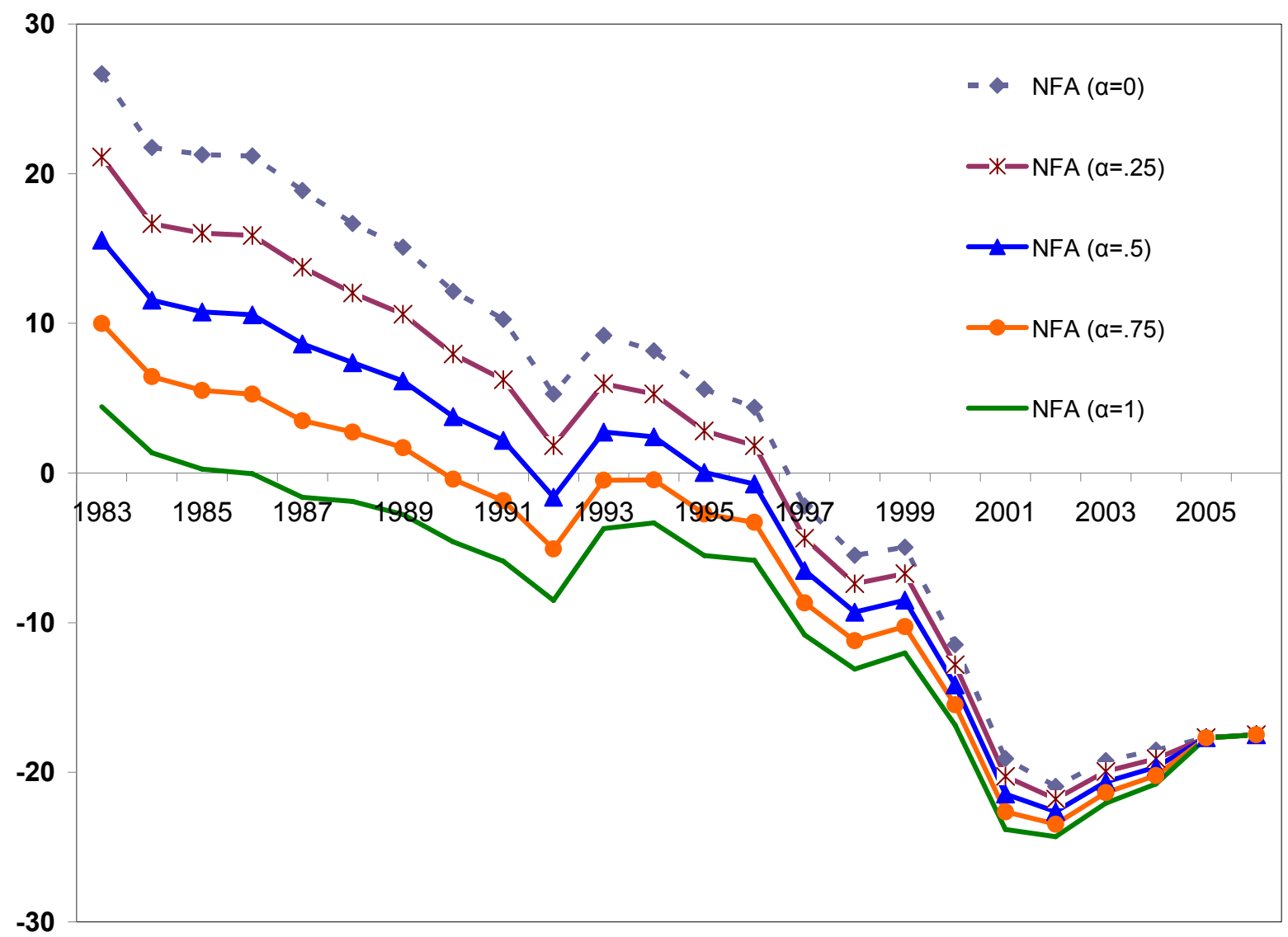


Table 1. The Dynamics of the U.S. International Investment Position, 1976-2006 (in percent of end-period GDP)

$1976-82 \quad 1983-92 \quad 1993-2001 \quad 2002-2006$

Change in total assets (FDI at current cost)

Change in total liabilities (FDI at current cost)

Change in IIP (FDI at current cost)

Change in total assets (FDI at market value)

Change in total liabilities (FDI at market value)

Change in IIP (FDI at market value)

Total financial outflows

Total financial inflows

Financial account

Gap: assets (FDI current cost)

Gap liabilities (FDI current cost)

Net Gap (FDI current cost)

Gap assets (FDI market value)

Gap liabilities (FDI market value)

Net Gap (FDI market value)

$\begin{array}{rrrr}20.0 & 19.3 & 39.3 & 46.9 \\ 15.0 & 31.3 & 54.0 & 52.0 \\ 5.0 & -12.0 & -14.7 & -5.1 \\ & & & \\ & 23.8 & 44.1 & 53.7 \\ & 34.6 & 62.7 & 52.6 \\ & -10.9 & -18.6 & 1.1\end{array}$

15.0

13.3

33.9

22.7

12.5

27.2

52.1

46.7

$-2.5$

13.9

18.2

24.0

5.0

6.0

5.4

24.2

2.5

2.6

4.1

1.9

1.8

3.5

5.3

18.9

$10.4 \quad 10.2$

31.0

$7.4 \quad 10.6$

5.9

3.0

$-0.4$

25.1

Note: Authors' calculations based on BEA data. 
Table 2. Price and exchange rate valuation effects, 1983-2006 (in percent of end-period GDP)

Valuation BEA (assets, FDI at current cost)

Valuation BEA (liabilities, FDI at current cost)

Valuation BEA (net, FDI at current cost)

Valuation BEA (assets, FDI at market value)

Valuation BEA (liabilities, FDI at market value)

Valuation BEA (net, FDI at market value)

Valuation LMF (assets, FDI at current cost)

Valuation LMF (liabilities, FDI at current cost)

Valuation LMF (net, FDI at current cost)

Valuation LMF (assets, FDI at market value)

Valuation LMF (liabilities, FDI at market value)

Valuation LMF (net, FDI at market value)
$1983-92 \quad 1993-2001 \quad 2002-2006$

$1.8 \quad 18.1$

$6.0 \quad 5.6$

$-4.2 \quad 12.5$

$6.9 \quad 25.5$

$12.4 \quad 5.9$

$-5.5 \quad 19.5$

$\begin{array}{lll}1.1 & 2.0 & 17.1\end{array}$

$\begin{array}{rrr}4.2 & 6.1 & 5.0\end{array}$

$-3.1 \quad-4.1 \quad 12.1$

$\begin{array}{lll}5.5 & 5.8 & 25.0 \\ 7.1 & 12.3\end{array}$

$\begin{array}{lll}7.1 & 12.3 \quad 5.8\end{array}$

Note: The top half of the table reports BEA data on the aggregate contribution of valuation effects (not available before 1989); the bottom half reports the results from implementing the LMF method described in section 2. 
Table 3. The Importance of Residual Adjustments, 1983-2006

(in percent of end-period GDP)

Residual BEA (assets, FDI at current cost)

1983-92 1993-2001 2002-2006

$3.6 \quad 15.5$

Residual BEA (liabilities, FDI at current cost)

$-4.1 \quad 8.4$

Residual BEA (net, FDI at current cost)

7.7

7.1

Residual BEA (assets, FDI at market value)

3.3

14.9

Residual BEA (liabilities, FDI at market value)

$-1.8$

8.7

Residual BEA (net, FDI at market value)

5.1

6.2

Residual LMF (assets, FDI at current cost)

4.8

3.4

16.4

Residual LMF (liabilities, FDI at current cost)

$-0.1$

$-4.3$

8.9

Residual LMF (net, FDI at current cost)

5.0

7.6

7.5

Residual LMF (assets, FDI at market value)

$\begin{array}{lll}4.9 & 4.4 & 15.3\end{array}$

Residual LMF (liabilities, FDI at market value)

0.3

$-1.7$

8.8

Residual LMF (net, FDI at market value)

4.7

6.1

6.5

Note: Authors' calculations. The top half of the table reports the BEA data on the aggregate contribution of the residual term (not available before 1989); the bottom half reports the results from implementing the LMF method described in section 2. The residual for assets and liabilities is particularly high in 2005 because the BEA started reporting asset and liability positions in derivatives that year. 
Table 4. Portfolio Assets and Liabilities: Stock-Flow Reconciliation (in percent of end-of-period GDP)

$\begin{array}{rrr}\text { Portfolio Debt } & & \\ \text { 1983-1992 } & 1993-2001 & \text { 2002-2006 } \\ 2.3 & 3.5 & 4.7 \\ 10.2 & 17.3 & 22.0 \\ -8.0 & -13.8 & -17.3 \\ & & \\ 1.4 & 3.2 & 2.5 \\ 9.9 & 19.2 & 24.3 \\ -8.5 & -16.0 & -21.9 \\ 0.2 & -0.6 & 0.5 \\ 0.5 & 0.4 & 0.0 \\ -0.3 & -1.0 & 0.5 \\ & & \\ 0.7 & 0.9 & 1.8 \\ -0.1 & -2.3 & -2.3 \\ 0.8 & 3.2 & 4.1\end{array}$

Change in Assets

Change in Liabilities

Change in Net Position

Cumulative Financial Outflows

Cumulative Financial Inflows

Cumulative Net Flows

Valuation (Assets)

Valuation (Liabilities)

Valuation (Net)

Portfolio Equity

Residual (Assets)

Residual (Liabilities)

Residual (Net)

1983-1992

1993-2001

2002-2006

Change in Assets

\section{7}

12.8

19.9

Change in Liabilities

3.8

12.3

9.1

Change in Net Position

0.9

0.5

10.8

Cumulative Financial Outflows

1.5

7.4

3.8

Cumulative Financial Inflows

0.5

5.8

2.9

Cumulative Net Flows

1.0

1.6

0.9

Valuation (Assets)

1.1

3.3

13.5

Valuation (Liabilities)

3.3

5.7

4.2

Valuation (Net)

$-2.3$

$-2.5$

9.4

Residual (Assets)

2.1

2.2

2.6

Residual (Liabilities)

$-0.1$

0.8

2.0

Residual (Net)

2.2

1.4

0.6

Note: residual is calculated as change in assets (liabilities) minus cumulative financial outflows (inflows) minus valuation. Source: authors' calculations based on IMF and BEA data. 
Table 5. Foreign Direct Investment: Stock-Flow Reconciliation (in percent of end-period GDP)

\begin{tabular}{|c|c|c|c|}
\hline & $\begin{array}{c}\text { Current Cost } \\
1983-1992\end{array}$ & $1993-2001$ & $2002-2006$ \\
\hline Change in Assets & 4.6 & 10.2 & 8.8 \\
\hline Change in Liabilities & 5.6 & 9.7 & 4.4 \\
\hline Change in Net Position & -1.0 & 0.5 & 4.4 \\
\hline Cumulative Financial Outflows & 4.7 & 11.1 & 6.1 \\
\hline Cumulative Financial Inflows & 5.8 & 12.9 & 4.4 \\
\hline Cumulative Net Flows & -1.1 & -1.7 & 1.7 \\
\hline Valuation (Assets) & 0.1 & -0.2 & 1.8 \\
\hline Valuation (Liabilities) & 0.4 & 0.1 & 0.5 \\
\hline Valuation (Net) & -0.3 & -0.3 & 1.2 \\
\hline Residual (Assets) & -0.2 & -0.7 & 0.9 \\
\hline Residual (Liabilities) & -0.6 & -3.3 & -0.5 \\
\hline \multirow[t]{2}{*}{ Residual (Net) } & 0.3 & 2.6 & 1.4 \\
\hline & $\begin{array}{c}\text { Market Value } \\
1983-1992\end{array}$ & $1993-2001$ & $2002-2006$ \\
\hline Change in Assets & 9.0 & 15.0 & 15.6 \\
\hline Change in Liabilities & 8.9 & 18.4 & 5.0 \\
\hline Change in Net Position & 0.1 & -3.4 & 10.6 \\
\hline Cumulative Financial Outflows & 4.7 & 11.1 & 6.1 \\
\hline Cumulative Financial Inflows & 10.3 & 12.9 & 4.4 \\
\hline Cumulative Net Flows & -5.7 & -1.7 & 1.7 \\
\hline Valuation (Assets) & 4.5 & 3.6 & 9.7 \\
\hline Valuation (Liabilities) & 3.3 & 6.3 & 1.3 \\
\hline Valuation (Net) & 1.2 & -2.7 & 8.4 \\
\hline Residual (Assets) & -0.1 & 0.2 & -0.2 \\
\hline Residual (Liabilities) & -0.2 & -0.7 & -0.7 \\
\hline Residual (Net) & 0.0 & 1.0 & 0.5 \\
\hline
\end{tabular}

Note: residual is calculated as change in assets (liabilities) minus cumulative financial outflows (inflows) minus valuation. Source: authors' calculations based on IMF and BEA data. 
Table 6. Holdings of Banks and Non-Banks: Stock-Flow Reconciliation (in percent of end-period GDP)

1983-1992 1993-2001 2002-2006

$\begin{array}{lrrr}\text { Change in Assets } & 7.6 & 12.9 & 12.9 \\ \text { Change in Liabilities } & 10.2 & 13.1 & 15.8 \\ \text { Change in Net Position } & -2.6 & -0.2 & -2.9 \\ & & & \\ \text { Cumulative Financial Outflows } & 5.4 & 12.1 & 10.6 \\ \text { Cumulative Financial Inflows } & 9.6 & 12.8 & 14.4 \\ \text { Cumulative Net Flows } & -4.3 & -0.6 & -3.8 \\ & & & \\ \text { Valuation (Assets) } & -0.1 & -0.2 & 0.5 \\ \text { Valuation (Liabilities) } & 0.0 & -0.1 & 0.4 \\ \text { Valuation (Net) } & -0.1 & -0.1 & 0.2 \\ & & & \\ \text { Residual (Assets) } & 2.3 & 1.0 & 1.8 \\ \text { Residual (Liabilities) } & 0.6 & 0.5 & 1.1 \\ \text { Residual (Net) } & 1.7 & 0.5 & 0.7\end{array}$

Note: residual is calculated as change in assets (liabilities) minus cumulative financial outflows (inflows) minus valuation. Source: authors' calculations based on IMF and BEA data. 
Table 7. Rates of Capital Gain

\begin{tabular}{|c|c|c|c|c|}
\hline & & 1983-1992 & $1993-2001$ & $2002-2006$ \\
\hline \multirow[t]{2}{*}{ Portfolio Equity Assets } & Full residual & 21.5 & 10.5 & 16.5 \\
\hline & $\mathrm{BEA} / \mathrm{LMF}$ & 9.4 & 7.2 & 13.4 \\
\hline \multirow[t]{2}{*}{ Portfolio Equity Liabilities } & Full residual & 9.6 & 12.4 & 7.9 \\
\hline & BEA/LMF & 9.8 & 10.9 & 4.4 \\
\hline \multirow[t]{2}{*}{ Portfolio Debt Assets } & Full residual & 5.1 & 1.6 & 8.5 \\
\hline & BEA/LMF & 1.7 & -1.1 & 2.2 \\
\hline \multirow[t]{2}{*}{ Portfolio Debt Liabilities } & Full residual & 0.8 & -1.4 & -1.5 \\
\hline & BEA/LMF & -0.1 & 0.3 & -0.4 \\
\hline \multirow[t]{2}{*}{ FDI assets (current cost) } & Full residual & -0.3 & -1.2 & 3.1 \\
\hline & $\mathrm{BEA} / \mathrm{LMF}$ & 0.2 & -0.2 & 2.1 \\
\hline \multirow[t]{2}{*}{ FDI liabilities (current cost) } & Full residual & 0.0 & -3.7 & -0.3 \\
\hline & BEA/LMF & 0.5 & 0.1 & 0.7 \\
\hline \multirow[t]{2}{*}{ Total Assets (FDI at current cost) } & Full residual & 2.4 & 2.3 & 7.3 \\
\hline & BEA/LMF & 0.2 & 1.2 & 5.1 \\
\hline \multirow[t]{2}{*}{ Total Liabilities (FDI at current cost) } & Full residual & 1.9 & 0.8 & 0.9 \\
\hline & BEA/LMF & 1.5 & 1.6 & 1.2 \\
\hline \multirow[t]{2}{*}{ Total Assets (FDI at market value) } & Full residual & 4.6 & 3.9 & 8.3 \\
\hline & BEA/LMF & 2.5 & 3.0 & 6.4 \\
\hline \multirow[t]{2}{*}{ Total Liabilities (FDI at market value) } & Full residual & 3.0 & 2.8 & 0 . \\
\hline & BEA/LMF & 2.5 & 3.2 & 1.0 \\
\hline
\end{tabular}

Note: BEA/LMF capital gains are calculated as the ratio of the price and exchange rate valuation term for year $t$ to the outstanding stock of the corresponding asset/liability at the end of year $t-1$. "Full residual" is the average rate of capital gain calculated by adding the entire residual term to the price and exchange rate valuation term. 
Table 8. Net Impact of Residual "Re-Allocation" on External Position, Capital Flows, and Valuation (in percent of end-period GDP)

1983-1992 1993-2001 2002-2006

\begin{tabular}{llccr} 
Portfolio Debt & Net Flows & 0.8 & 3.2 & 4.0 \\
& Net Valuation & 0.0 & 0.0 & 0.1 \\
Portfolio Equity & Net Flows & 2.0 & 1.3 & 0.5 \\
& Net Valuation & 0.1 & 0.1 & 0.1 \\
\multirow{2}{*}{ FDI at current cost } & Net Valuation & 0.3 & 2.6 & 1.4 \\
FDI at market value & Net Valuation & 0.0 & 1.0 & 0.5 \\
\multirow{2}{*}{ Banks and Non-Banks } & Net Flows & 0.9 & 0.5 & -0.1 \\
& Net Valuation & 0.0 & 0.0 & 0.0 \\
& Position & -0.9 & -0.1 & -0.8
\end{tabular}

Note: the table reports the difference between the revised cumulative capital flows, revised valuation effects, and revised changes in the external position on the one hand, and the official figures (reported in Tables 4-6) on the other hand. 